AperTO - Archivio Istituzionale Open Access dell'Università di Torino

\title{
Learning democratic thinking: a curriculum to philosophy for children as citizens
}

\section{This is the author's manuscript}

Original Citation:

Availability:

This version is available http://hdl.handle.net/2318/1693712

since 2020-04-22T23:08:41Z

Published version:

DOI:10.1080/00220272.2015.1088064

Terms of use:

Open Access

Anyone can freely access the full text of works made available as "Open Access". Works made available under a Creative Commons license can be used according to the terms and conditions of said license. Use of all other works requires consent of the right holder (author or publisher) if not exempted from copyright protection by the applicable law. 


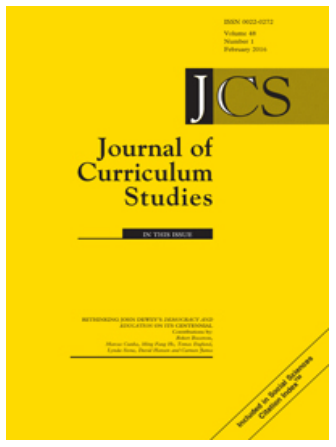

Journal of Curriculum Studies

\section{Learning democratic thinking: a curriculum to philosophy for children as citizens}

\section{Diego Di Masi \& Marina Santi}

To cite this article: Diego Di Masi \& Marina Santi (2016) Learning democratic thinking: a curriculum to philosophy for children as citizens, Journal of Curriculum Studies, 48:1, 136-150, DOI: 10.1080/00220272.2015.1088064

To link to this article: http://dx.doi.org/10.1080/00220272.2015.1088064

曲 Published online: 03 Nov 2015.

Submit your article to this journal ¿

Џll Article views: 774

Q View related articles $₫$

View Crossmark data $\asymp$ 


\title{
Learning democratic thinking: a curriculum to philosophy for children as citizens
}

\author{
Diego Di Masi and Marina Santi \\ Department of Philosophy, Sociology, Pedagogy and Applied Psychology (FISPPA), University of Padova, \\ Padova, Italy
}

\begin{abstract}
In 2008, the Italian government passed a law that introduced a new school subject: Citizenship and Constitution. The law requires all students between the ages of 3 and 16 to attend almost $400 \mathrm{~h}$ of Citizenship Education during their 13 years of compulsory schooling. The law is part of an increasingly wider international effort that focuses on improving pupils' knowledge of and involvement in society by exposing them to history and civic content. The aim of this article was to present a Citizenship Curriculum and its possible implementation in schools and other areas. Taking into account the Curriculum Transposition model, we propose both an External Transposition, which analyses international and national documents about Citizenship Education, and an Internal Transposition, in order to design a curriculum that will enable children to participate in decision-making processes and improve their complex thinking. The Implemented Citizenship Curriculum (Polißophia project) was introduced into the Municipal Council of Children, and the Philosophy for Children method was applied in order to help children make moral judgments, a fundamental component of democratic thinking.
\end{abstract}

\section{KEYWORDS}

Citizenship Education; participation; curriculum design; Philosophy for Children; moral judgments

\section{The State of art of Italian Citizenship Education}

In 1958, Presidential Decree No. 585 entitled 'Programs for Teaching Civics in Institutes and Secondary and Artistic Schools' introduced Citizenship Education into schools for the first time in the history of the Republic of Italy.

In 1958, the Republic of Italy was just 10 years old, and the State's legal service needed to create'mutual cooperation relationships' between School and Life. Since that time, there has been much discussion about the Italian education system, as it was believed that subject-based teaching in schools was unable to create and pass on shared values without the support of other institutions. The introduction of this Presidential Decree underlined the role of schools in promoting critical awareness; it aimed to introduce pupils to real-life and avoid constructing a career-based education system. The introduction of the decree suggested that schools were acknowledging their limits when it came to meeting society's needs; however, 
it also showed that schools were not shirking their educational responsibilities because teachers 'must be stimulators of moral and social conscience before being teachers of their subject'. Therefore, Civics is a means 'of showing students how individual wills can flow freely yet act together', adding value to the interests of every individual within collective work and ensuring personal action is meaningful wherever 'shared intentions and effort' coincide.

A further attempt to define Civics came with the Italian Ministerial Decree of 9 February 1979 , which regulated 'programs, teaching hours and final examinations for State middle schools.' The first innovation was the definition of the relationship between schools and all spheres of life. In the decree, the word 'Life' is no longer the polar opposite to 'School'; instead it is replaced by the term 'local communities' in a bid to create a new secular vision of citizenship. The role of an educator was no longer to stimulate moral conscience, but to compare cultural statements openly in order to shape pupils' personality so that they would observe moral and civil conscience. Thus, Civics became part of the school curriculum and was seen as an interdisciplinary link between all forms of learning.

Since 1979, the key role of Civics has been to imbue students with 'a critical skill that allows people to establish behaviour criteria, to understand the role of the rules that allow society to develop correctly, and to define the relationship between individual freedom and community needs'.

The next main step in Italy's history of Civics was Presidential Decree No. 104 in 1985, which 'approved the new curricula for primary schools'. The difference between the 1979 and 1985 decrees, which govern Italy's middle and primary schools, respectively, is that the latter refers openly to the Italian Constitution, and even quotes it directly by stating that 'all citizens are equal and have equal dignity in the eyes of the law without any difference or distinction' (Article 3 of the Italian Constitution).

Another innovation was the appearance of the concept of 'education for democratic cohabitation' and a declaration of the principle of laity in public schools, as well as references to Europe. All of these features introduced a radically new interpretation of citizenship, which was also strengthened by the intention to stimulate students so that they became aware of their own ideas and took responsibility for their own actions.

Although this directive recognized that all school subjects had a role in training citizens, it complied with contemporary legislation and entrusted history teachers with the task of teaching Civics, a subject that 'makes an autonomous contribution to a student's final evaluation'. The directive did not draft a Civics curriculum, but encouraged 'reflection upon the role of education and school in modern society', and suggested that students be involved in the decision-making process within the school community, which is important if citizenship is to be interpreted as a commitment to public life.

Citizenship Education became the focus of fresh interest when the Italian Parliament approved Law No. 169 on 30 October 2008. This law contained a key terminology difference to previous attempts to define Civics in that it recommended the 'Constitution' be used as a 'map of values' to construct a personal identity, as well as a local, national and human one, that could lead to active citizenship.

The role of the Constitution as a foundation for community life was reinforced by a policy dated 4 March 2009 that promoted the experimentation of teaching 'Citizenship and Constitution'. The policy stated that school should become a'training-ground for democracy' and a place where students could learn 'knowledge of legality' by participating in society and their local community, as well as in European and global communities (Indicazioni per 
Table 1. Curriculum Transposition (McCowan, 2008).

\begin{tabular}{lll}
\hline & Ends & Means \\
\hline Ideal & Ideal person society & Formal curriculum program (Official Curriculum) \\
Real & Effect on student (Achieved Curriculum) & Real implemented curriculum (Taught Curriculum) \\
\hline
\end{tabular}

il Curricolo, 2012). Furthermore, the ministerial paper's interpretation and its emphasis on a mark for Conduct made the relationship between citizenship and legality one of the most controversial aspects of this policy, as it attempted to replace emancipation and radical change with an approach that favoured maintenance of the status quo.

Analysis of Italy's national Citizenship Education policy reveals an increased commitment and effort to go beyond improving pupils' knowledge and engagement by exposing them to history and civic content during their compulsory schooling, mainly as part of history and social studies curricula.

Today, the debate that started at school and society level has faded into the background somewhat, despite being promoted by a law. The cause of this gradual disinterest in the matter can be traced back to poor coordination between the framework of the law and the tools that were supposed to guide and support the implementation of educational practices in schools. One example is that although the law devoted $400 \mathrm{~h}$ of school time to 'Citizenship and Constitution' and introduced a school-report mark for 'Conduct', its autonomy was hampered by a severe lack of financial support and specific teacher-training, which affected the interdisciplinary approach that had inspired it.

This analysis also enables us to outline a process of mediation and adaptation that can be used to analyse a curriculum, as McCowan's Curriculum Transposition model (McCowan, 2008) suggests.

\section{Curriculum Transposition}

When savant knowledge needs to be taught and when knowledge is removed from its scientific context, it suffers what Chevallard (1985) calls a Transposition didactique (Verret, 1975). Didactic transposition turns savant knowledge into taught knowledge, as the teacher adapts it for classroom practice, which is always unique. This transposition is made in three phases (Perrenoud, 1998): (1) Turning society's knowledge and practices into a Formal Curriculum Program (Official Curriculum); (2) Constructing a Real Implemented Curriculum, which will be taught in the classroom; and (3) the Achieved Curriculum and its effect on student learning.

This mediation and adaptation process takes place on two levels. The first is called External Didactic Transposition and occurs between society and the education system; it is carried out by everyone involved in the teaching-learning process outside the education system. The second level - Internal Didactic Transposition - is carried out within an 'Educational Triangle' (Chevallard, 1985); it consists of three components: the teacher, the student and knowledge. The first level enables a Formal Curriculum to be built and the second enables the Real Curriculum to be processed.

McCowan took this model and adapted it to Citizenship Education by fitting it into a scheme that takes into account both the Ideal/Real dimensions and the Ends/Means. He created what he called Curriculum Transposition (McCowan, 2008). 
Table 2. Curriculum Transposition applied to Citizenship Education.

\begin{tabular}{lll}
\hline & Ends & Means \\
\hline Ideal & Democracy and democratic thinking & 'Citizenship and Constitution' \\
Real & Complex thinking (research results) & Polisofia \\
\hline
\end{tabular}

McCowan's model is important to our Citizenship Education proposal for two reasons. One is because it introduces the Ideal/Real dimension, which is a problematic issue within the debate on democracy. According to Hermet (1993), there is a permanent democracy deficit which is the product of the tension between democracy as a value (Ideal Dimension) and democracy as a form of government (Real Dimension). In these terms, Citizenship Education becomes a means for reducing this deficit, as it promotes civic virtues; these virtues make democratic institutions sustainable (Bolivar, 2007) and make democracy itself a perfectible project (Bîrzéa, 2000).

The second point covers the relationship between Means and Ends, which is also central to democracy. Bobbio (1976) says that compliance with the rules that guarantee the widest citizenship participation in the public decision-making process is not sufficient to define a State as democratic, in that means must also be consistent with purposes.

Table 1 shows McCowan's four levels of Curriculum Transposition in his Citizenship Education framework. The first box establishes the Ideal and Ends dimensions, i.e. the ideal citizen and society our culture aims to build. These dimensions are dealt within international documents, such as the UN Convention on the Rights of the Child and the Council of Europe's Education for Democratic Citizenship Project. See also the body of expert knowledge in scientific literature. The second box is for the Official Curriculum (McCowan, 2008) or Formal Curriculum (Perrenoud, 1998); it is covered by government proposals for Citizenship Education. The third box is for the curriculum taught in class (Real Curriculum), which is the result of the Internal Transposition (Perrenoud, 1998) conducted by the teachers; it is the place of the curriculum in the real world, historically and culturally. The fourth and final box contains the process's influence on the student: the Achieved Curriculum. Achieved Curriculum is very important in Citizenship Education because it represents the real citizenship that students achieve. Indeed Curriculum Transposition follows the concept of real citizenship, which may even offer new stimulus to ideal citizenship, as it generates critical reflection on the concept of citizenship and how to exercise it. The curriculum does not end at the fourth transposition step, but still arouses debate about the ideal dimension, and thus generates a new curriculum.

\section{Citizenship Curriculum}

The previous analysis enables us to outline a process of mediation and adaptation that can be used to design a real implemented curriculum, in accordance with McCowan's Curriculum Transposition model (2008). Our research project calls this curriculum Polißofia. In order to understand the reasons for teaching argumentative skills in Citizenship Education, as per the Curriculum Transposition model applied to Citizenship Education (Table 2), the first step is to clarify the ideal/ends of democracy in today's society, as described in international documents and academic literature on Citizenship Education. 
Below is a presentation of both the External and Internal Didactic Transposition behind the design of our Polißofia curriculum. Poli§ofia is also inspired to Kelsen's idea of democracy, as he states that democracy highlights the interconnection between freedom and equality (Kelsen, 1984), where freedom means rejecting heteronomy, and equality means that nobody has the right to exercise any form of dominance over other people (Petrucciani, 2014).

These assumptions lay down a political and educational challenge: how can freedom and equality can be made compatible in a democratic legitimacy order? According to Rousseau and Kelsen, the only way we can accept a democratic legitimacy order without losing freedom and equality is to take part in decision-making processes so that we submit to the law that we have given ourselves (Petrucciani, 2014).

From an educational perspective, it is crucial to promote argumentative skills and opportunities to exercise them in order to ensure that Citizenship Education involves dialogue and 'free and reasoned deliberation among individuals considered as moral and political equals' (Benhabib, 1996, p. 68).

Finally, when we examine the Achieved Curriculum or the effect of philosophical dialogue on pupils, we focus on moral judgment as a condition for just and fair deliberation (Power, Higgins, \& Kohlberg, 1989).

\section{External Didactic Transposition}

The Council of Europe defines a citizen as 'a person co-existing in a society' (O'Shea, 2003). This definition is important for two reasons: the first is that the concept of citizenship is stated not only in terms of a relationship with a Nation State, as it also transcends national borders and creates a concept of community that encompasses the local, national, regional and international levels in which an individual lives. The second reason is that this concept of citizenship provides a status and confirms that citizenship has a social role. We exercise our citizenship not only with our right to vote, but also with our actions, as they have an impact on community life and the public sphere that each individual shares with others. For our purposes, O'Shea's definition is particularly interesting because it highlights the relational dimension of citizenship where individuals - with their opinions, interests and values - have to explore how to live together and learn how to choose between different alternatives offered by others. From this perspective, dialogue becomes a co-existing tool, a theoretical and ethical principle: the duty to understand others (Petrucciani, 2014).

We can summarize the various positions on citizenship in two main ways. For some, citizenship is a formal concept, a status that confers rights and responsibilities upon the citizens within a community. According to Bolivar (2007), citizenship as a formal concept is typical of the traditional Citizenship Education framework, which aims to provide information on rights and duties and to develop uncritical respect for the establishment and its conventional values.

The second way interprets citizenship in the broadest sense as participation and engagement in public life. Citizenship Education, therefore, implies teaching the skills needed for debate and public deliberation in order to promote opportunities for participation both in and out of school (Bolivar, 2007).

The first stance interprets citizenship as a product, and the second interprets it as citizens being able to exercise critical and reflective thinking in order to change society; thus citizenship becomes a practice,'a social learning process in public spaces' (Bolivar, 2007, p. 27). 
McLaughlin defines these two positions as 'minimal' and 'maximal'. A minimal approach to Citizenship Education provides information about how democracy and its institutions function, interpreting citizenship as a legal status. A maximal approach, however,'requires the development of a critical understanding of social structures and processes, [...] and "virtues" that allow students to change them' (McLaughlin, 1992, p. 238); it is agency-based whereby Citizenship Education means promoting the participation of young people.

Both approaches are built on three separate, but complementary, pillars: literacy policy, development of values and attitudes for responsible citizenship and active participation (European Commission, 2005). Their only distinction is that the minimal approach is not sufficient for the construction of active, responsible citizenship.

The first pillar involves the acquisition of theoretical knowledge about human rights and democracy, as well as about the functioning of political institutions and the social, historical and cultural aspects of one's own country. The second concerns the development of the capabilities needed to resolve conflict peacefully, to respect oneself and others, and to develop critical thinking. The third regards the development of the capabilities needed for active, critical and responsible participation in school and community life in order to ensure that the rules and principles of democracy are experienced directly.

Each of these three dimensions can be linked with three skill levels that foster Citizenship Education (Hoskins, Villalba, Van Nijlen, \& Barber, 2008; Torney-Purta, Lehmann, Oswald, \& Schulz, 2001). The first is cognitive and involves the development of autonomy and critical sense, which requires the acquisition of accurate, documented knowledge and the ability to analyse and reflect on the main issues of democracy and citizenship, both of which are needed to develop reflexive citizenship (Santerini, 2010). This first level, which Audigier (2002) also calls compétence cognitives, comprises the legal and political knowledge needed to understand: (a) public and democratic institutions and the rules of community life; (b) the history and culture of the contemporary world; and (c) the principles and values of human rights and democratic citizenship.

Santerini calls the second level 'living citizenship', which is based on internalized rules and democratic values (Santerini, 2010). We also find these competences in Le concepts de base et compétences-clés pour l'éducation à la citoyenneté démocratique (Audigier, 2002), in which they are defined as 'ethical competences and value choices'. In his work, Audigier emphasizes the role of values in the construction of individual personality and in relationships with others. This dimension includes both rational and affective emotional aspects.

The third level of deliberative citizenship (Santerini, 2010) encompasses participatory and decision-making skills, which Audigier calls 'social competences'. These competences are related to a person's ability to cooperate, to resolve conflicts and to take part in public debate.

\section{Internal Didactic Transposition}

In the previous section, we introduced two interpretations of Citizenship Education - minimal and maximal - and we also illustrated the goals and related skills presented in European documents and scientific literature. This section now aims to translate this framework into a real context, as we focus on the opportunities and abilities required to guarantee authentic citizenship, as achieved in Polißophia, the Implemented Citizenship Curriculum based on Philosophy for Children (ability) and applied to the Municipal Council of Children (opportunities). 
The Municipal Council of Children (MCC) is a local government tool that promotes the participation of younger generations in the democratic life of their community in association with schools. Since its launch, the MCC has dealt with urban environment issues. In recent years, there has been a flurry of initiatives involving citizens in issues that had hitherto been the sole responsibility of 'experts'. This is due to growing awareness of childhood deprivation, reduced opportunities for socialization, inadequate urban planning, neglect of citizens' needs and wishes, as well as extensive discussion in civil society and scientific communities as to the environmental risks of unsustainable economic growth. Consequently, increasing focus has been placed both on third-generation rights, including health, welfare and environmental protection, and on multiplying education to include environmental education, health education and the right to education.

The MCC is an elected body whose composition, age and number of councillors is governed by the rules and regulations adopted by each local institution. Those elected are usually girls and boys aged between 9 and 13 years old, and the number of councillors depends on the number of District Schools. The councillors, who are elected by their classmates, can choose a Mayor to represent the MCC at official meetings. Once installed, the councillors can work in small groups (commissions) and with their classmates to draw up proposals for the MCC. In the Polißophia project, the MCC can be interpreted in two ways: as an activity, which considers it as a space for public deliberation, and as a context, which enables it to be read as a model for deliberative democracy. In both interpretations, the MCC is an opportunity to develop and practice skills, such as giving good reasons, making good distinctions and connections, making valid inferences, hypothesizing, asking good questions, using and recognizing criteria, calling for relevance, seeking clarification, offering alternative points of view, building logically on the contributions of others, posing counter-examples, asking for reasons, testing and so on (Lipman, Sharp, \& Oscanyan, 1980; Sharp, 1993).

Philosophy for Children (P4C) is an international movement that aims to give voice to childhood thinking through philosophical practice. The methodological core of the curriculum is the construction of Communities of Inquiry (Col), which involve reasoning and argumentative skills, foster creative imagination and develop caring dispositions (Santi \& Di Masi, 2010). Founded by Matthew Lipman in the 1970s, P4C comprises a curriculum that emphasizes the formative dimension of philosophy with a Col, which explores the philosophical aspects of experience. P4C takes a fresh look at education, as it eschews the simple transfer of knowledge from teachers to students, and promotes 'an approach that puts the child at the centre and emphasizes learning by discovery and experiment, and the construction of knowledge' (Vansieleghem, 2005, p. 19). Rather than seeing philosophy as the history of ideas, we should look at it as a reflective activity that uses refined, everyday language and enables us to give deeper meaning to the world and to humanity (Santi, 2006, p. 56). Consequently, philosophical dialogue becomes a dialogical activity, which implies the involvement of at least two voices/points of view, the meaning of which is the product of difference (Bakhtin, 1981).

It is a general aim of Philosophy for Children to include the voices of every member of the community on the grounds that the more voices are heard, the greater will be the possibilities of reaching a general and appropriately representative consensus. On this view the input of children is of particular value since it is children who keep asking questions when adults have lost the ability so to do. The capacity to use tools and skills, to adopt strategies and to participate and inquire have become basic presuppositions of a democratic society. So too, Philosophy for Children is based on the proposition that critical thinking and dialogue are the necessary 
conditions for emancipating children from determination and for transforming them into democratic, free citizens. (Vansieleghem, 2005, p. 20)

P4C highlights the role that public and shared dialogue in Col could play in teaching the critical, creative and caring dimensions of complex thinking, thus offering the opportunity for autonomous thinking (Santi \& Di Masi, 2014). According to Young, who explored how different genres of classroom conversation developed children's thinking (Young, 1992), a dialogue based on child participation in shared reasoning and argument evaluation promotes authentic experience, increasing critical autonomous thinking and preventing indoctrination.

Col is seen as a given historical and cultural context, in which children learn through peer-to-peer and child-to-adult communication (Lave \& Wenger, 1991; Rogoff, 1995, 1996; Vygotskij, 1978). Knowledge is constructed within the Col and it is the result of interpreting and negotiating shared meaning in a dialogue that occurs during practical and real-life problems (Dewey, 1915; Lipman, 2003; Santi, 2006). A Col is the place in which people can reflect upon experience and co-construct new meaning, a privileged place that facilitates dialogue based on the interpersonal exchange of thoughts and the desire to reach a consensus rather than a simple agreement.

\section{Poli§ophia project: Real Implemented Curriculum}

Polißophia is a Citizenship Education research project that was conducted in Rovigo, northeast Italy, between 2008 and 2010. The aim of Polißophia was to turn the MCC and the classes of elected councillors into Communities of Philosophical Inquiry in order to develop complex thinking (Lipman, 2003).

In accordance with the Curriculum Transposition model, Polißofia was viewed as a real implemented curriculum for Citizenship Education to support children's agency in terms of abilities and opportunities, providing spaces and places for discussions and increasing argumentative and reasoning skills that would lead to better deliberation.

Polißophia had three levels: the Council, Commissions and Classes of Councillors. The Council comprised forty-one $9-13$ year olds elected by their classmates. Their term lasted two years and the Council met once every three months to discuss the Commissions' proposals. The project involved all of the school districts in the municipality of Rovigo.

Four commissions were established as follows: (1) Environment and Transport; (2) Schools and Partnerships; (3) Sports and Music; and (4) Tourism and Culture. Issues and the composition of commissions were established on the basis of the candidates' programs, the children's interests, the councillor's age, and how the six school districts were represented in the commissions. The commissions met once a month and their work was also supported by local associations.

The Classes of Councillors worked alongside the elected MCC so that everyone felt they belonged to their community and had a sense of the value that comes from taking responsibility for their actions.

By promoting philosophical dialogue (P4C) in authentic contexts of participation (MCC), Poli§ophia contributes to the development of moral thinking in at least two ways. The first is that philosophical practice aimed at promoting citizenship and civic decision-making involves the caring dimension of complex thinking (Lipman, 2003; Santi, 2006), which emerges in open-mindedness, respect for others' opinions, empathy and listening. Primarily, however, 
democratic discussion is a 'practical' discussion, that is a discussion on values and decisions. The aim of a discussion in a democracy is to reach a consensus in order to deliberate and to motivate citizens to act (Walton \& Krabbe, 1995). Consequently, according to Dewey (1915), in every deliberation, the consequences of our decision/action are part of the process; every deliberation takes into account the consequences and the implications for other people, including those outside the decision-making process. As a result, it is deeply moral.

\section{Participants}

Although the P4C curriculum was implemented in all classes that provided a councillor, we have decided to present data collected in three classes. This choice was due to the following reasons:

- They were the three classes in which we conducted the P4C sessions as facilitators over the two years.

- Sixth-grade classes (11 year olds) ensured the continuity of the class group throughout the research period.

- They are the classes of the two schools that authorized us to administer the tests, even in the classes that did not take part in the project but acted as a control group.

The experimental group was formed of three sixth-grade classes (54 children). The P4C Program was implemented in each classroom (one hour per week, over nine months, under the supervision of Col facilitators, who are Philosophy for Children experts); specific materials were created for the project in line with the P4C curriculum. The control group was formed of three sixth-grade classes selected from the same school as experimental groups ( 52 children).

\section{Intervention}

In accordance with the Philosophy for Children curriculum, the Council, Commissions and Classes were to be converted into Communities of Philosophical Inquiry in order to develop complex thinking. Thirty-one classes were involved during the first year of the research (2008/2009) and 26 were involved in the second year (2009/2010). Each class took part in 20 one-hour sessions over the two years. The first 12 took place from February to May 2009 and the remaining eight from November to January 2010. The texts used to facilitate philosophical discussions were the unpublished stories inspired by the principles of the Italian Constitution, commission documents and some moral dilemmas considered useful for starting philosophical discussions.

The unpublished stories were written to introduce principles, such as freedom, justice, equality and rights through the daily experience of children (Lipman, 2003; Lipman et al., 1980) as per the tradition of P4C literature. The commission documents were used to create a link between the councillors and their classmates, while the moral dilemmas were chosen to facilitate the construction of arguments for and against the alternatives presented in the stories (Lind, 2008).

After reading the stories, individually or in groups, each child asked a question. The questions were written on a poster in order to collect and present the interests to the community. When all the questions had been written, the agenda was closed and the facilitator helped the community to share meaning and clarified any doubts. This first phase may also 
include a search for analogies or points-in-common, as well as for any divergent opinions or creative perspectives. Once the community had decided on a main topic, the philosophical discussion was opened and the children shared their positions and reasons by following the Inquiry Talk model (Santi, 2007), which combines heuristic and deliberative aspects (Wegerif, 2008; Santi, 2007; Wegerif, Mercer, \& Dawes, 1999). Inquiry Talk is based on 11 pragmatic rules: (1) Col participants are encouraged to speak with all of the other members; (2) Col participants must reflect before speaking; (3) All relevant information is shared; (4) Reasons are expected; (5) The structure of reasoning is important; (6) Challenges are accepted; (7) Inquiry talk is built on others' ideas; (8) Alternatives are discussed before a decision is taken; (9) The process is self-corrective; (10) The Col seeks to reach a consensus; and (11) The Col takes responsibility for its decisions.

In P4C, the role of teachers also changes, as they become facilitators. Their function shifts from content supervision to procedural supervision, as they scaffold the children in their intersubjective dialogue, helping them to construct knowledge, a process that will enable them to develop, among other things, empathy and a sense of equity and justice that defines morality (Bloom, 2013).

\section{Instruments}

We chose the Moral Judgment Test (MJT) (Lind, 1985) to assess whether participation in the Community of Philosophical Inquiry promotes the development of moral judgment, and to analyse the philosophical discussions conducted in the classroom. The MJT was administered at the beginning and at the end of the 20 sessions. The pre-test was administered individually in February 2009 and the post-test in April 2010.

The MJT was developed in 1976 by Georg Lind, a psychologist and student of Kohlberg. It aims to overcome the limits of the instruments used to evaluate moral thought (Moral Judgment Interview and DIT), which were inspired by Kohlberg's work. The MJT measures moral competence (C-index) and is based on a dual approach: in addition to its cognitive dimension, the test also measures the affective dimension that the subject expresses towards the suggested topics.

The MJT is composed of two dilemmas: the first is known as 'The workers' dilemma' and the second as 'The doctor's dilemma'. By 'dilemma', we mean a situation in which there are two alternatives, both equally undesirable.

After reading the story, subjects are asked to judge the choice of the protagonist and then to express their opinion (Likert scale from 'completely wrong' -2 to 'absolutely right' +2 ) on the arguments proposed. Each dilemma includes 12 arguments, including six 'for' and six 'against' the decision of the story's protagonist. Arguments are constructed so as to present different levels of moral judgments from Kohlberg's model (pre-conventional, conventional, post-conventional).

The MJT outlines dilemmas in which the protagonist must make a choice that requires overstepping a law or a moral principle. The test-taker's responses are not interpreted individually, but as a whole.

The MJT produces two indices. The first one is a stage-preference score. Since each of the six stages contains four arguments, the one that receives the highest score is the favourite stage. This index, however, measures only aptitude and not cognitive structure. The second index, or C-Index, measures moral structure. 
Table 3. Description of experimental and control groups.

\begin{tabular}{llccc}
\hline School & Group & Male & Female & Total \\
\hline Alpha & A (experimental) & 6 & 10 & 16 \\
& D (experimental) & 7 & 14 & 21 \\
& C (control) & 9 & 9 & 18 \\
Beta & E (control) & 12 & 6 & 18 \\
& A (experimental) & 7 & 14 & 21 \\
& C (control) & 10 & 8 & 18 \\
\hline
\end{tabular}

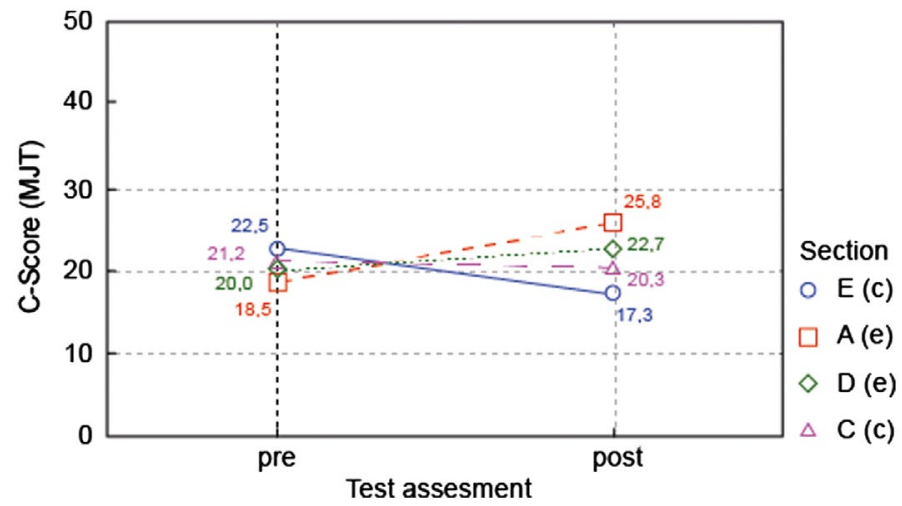

Figure 1. The effect of intervention in School 'Alpha' rxy $=0.37 ; F(3.69)=2.93 ; p<0.0394$.

The most interesting aspect of this index is that it does not determine which stage has the highest score, but identifies the test-taker's consistency in evaluating the four items within the same stage. 'The main point is that $C$ score represents the participant's consistency of rating for all groups of stage-typed items rather than the participant's preference for a specific stage' (Rest, Thoma, \& Edwards, 1997).

According to Lind, consistency is a measure of structure, since moral competence is the ability 'to appreciate a certain moral principle independently of the fact, whether or not it agrees with one's opinion on a particular issue' (Lind, 2008; Kohlberg, 1984).

Since each stage represents a moral principle, the fact that its associated arguments are judged equally, regardless of their opinion on the dilemma, indicates the level of value attributed to moral principle. 'For Lind the appreciation shown by consistency rating is the essence of moral competence' (Rest et al., 1997).

Competence is expressed in terms of consistency because, when the arguments are assessed, moral quality is judged from the perspective of the test-taker's principles and values, and is not based on the choice made by the protagonist.

\section{Results: Achieved curriculum}

The results presented in this study refer to two groups $(N=112)$ : the first is the experimental group consisting of three classes of sixth-grade pupils $(N=58$, Mean $=11.36, S D=0552)$; the second is the control group, which came from the same schools as the experimental group $(N=54$, Mean $=11.54, \mathrm{SD}=0638)$. The classes come from two different schools (Table 3$)$ : 


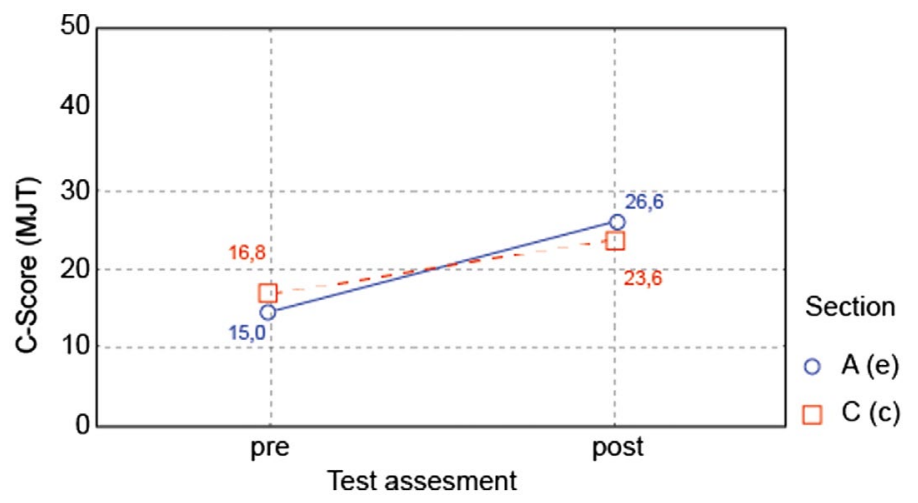

Figure 2. The effect of intervention in School 'Beta' rxy $=0.14 ; F(1.37)=0.66 ; p<0.4213$.

School 'Alpha' provided Section A and D (experimental group) and Section C and E (control group); and School 'Beta' provided Section A (experimental group) and Section C (control group) ${ }^{1}$.

When compared to the effects on the classes at School 'Alpha', Figure 1 shows that the $\mathrm{C}$-index rises in experimental classes. The difference between the means of the $\mathrm{C}$-index (pre-post test), increase by 7.3 in section $A$ and by 2.7 in section $D$, while decreases in the control group (0.9 in Section C and to 5.2 in Section E).

As for the results at School 'Beta', we note an increase in the C-index value in both classes. However, the increase in the experimental group is greater than in the control group (Figure 2).

The C-index value in the Section A pre-test is equal to 15.0, and in the post-tests, it is 26.6, an increase of 11.6. However, although the Section $C$ pre-test starts with a higher C-index value than Section A (16.8), in the post-test the C-index reaches a value of 23.6, an increase of 6.8 .

\section{Conclusion}

Over the last 60 years, the concept of citizenship in Italy has undergone a radical change. Citizenship Education policies have moved towards what McLaughlin (1992) calls a maximal approach, and today they have a more agency-based perspective that focuses on participation. However, the debate about which strategy should be adopted to develop values and responsible attitudes to guarantee a living citizenship (Santerini, 2010) is still open. The Curriculum Transposition model has become a useful tool for guiding teachers in designing education. External Didactic Transposition, for instance, may help to establish a suitable theoretical framework and viable goals, as well as clarify the main concepts involved. Internal Didactic Transposition, however, supports teachers in real context analysis and enables them to identify resources and obstacles so that they can achieve the learning outcomes and performances set.

Polißophia is a Citizenship Education project that links school with community; it enhances existing deliberative experiences (e.g. the MCC) and improves educational curricula (e.g. P4C) by developing the competences and attitudes needed for authentic deliberation. The etymology of 'deliberation' refers on the one hand to'setting free' and on the other to'the act 
of removing from a set of scales' (de-libra), an action which is possible only after all options have been considered, weighed up, evaluated and judged.

According to Lipman, good deliberation can be achieved if we develop skills such as making good distinctions and connections, making valid inferences, hypothesizing, using and recognizing criteria, seeking clarification, testing and so on. We must also, however, consider our ideals, values and moral judgments, which are part of human experience. In our research, the hypothesis that practicing philosophical dialogue in a Community of Philosophical Inquiry increases capacity for moral judgments was confirmed by the results of the MJT, which shows that the experimental group improved its ability to make moral judgments, but the control group did not.

Col dialogue plays a fundamental role not only in explaining the critical and creative dimensions of Lipman's complex thinking (2003), but also in understanding the dual meaning of caring thinking, which P4C considers as 'taking care' and 'value thinking' (Di Masi, 2012). According to Biggeri and Santi (2012), P4C and its commitment to enhancing child development both in and out of school may be considered as an authentic experience, during which children and young people think about (and decide) what they want to be (and value being), which become fundamental conditions if we are to tackle the challenges of contemporary democracy.

\section{Note}

1. The letters $A, D, C$ and $E$ are codes to identify the different classes involved in the research.

\section{Acknowledgements}

The research presented in this paper, conducted by Diego Di Masi during his PhD studies under the supervision of Marina Santi, was supported by the Cassa di Risparmio di Padova e Rovigo Foundation (CARIPARO Foundation). The authors thank students, parents, teachers and the political and administrative staff of the Municipality of Rovigo, who have contributed to the Polißofia project with their enthusiasm and competence.

\section{Disclosure statement}

No potential conflict of interest was reported by the authors.

\section{Notes on contributors}

Diego Di Masi is a postdoctoral researcher at the Department of Philosophy, Sociology, Pedagogy and Applied Psychology (FISPPA) at the University of Padova (Italy); email: diego.dimasi@unipd.it. His interests include inclusive education, collaborative practices and community-based participatory research in social and educational contexts. He is an expert in 'Philosophy for Children' and participatory methodologies with children and young people. He is consultant for local and national public agencies in child protection and social inclusion. His recent publications are on citizenship education, curriculum design, decision-making processes and transformative learning.

Marina Santi holds a PhD in Educational Sciences and is a full professor in Didactics and Special Education. She works in the Department of Philosophy, Sociology, Pedagogy and Applied Psychology at University of Padova, Italy. Her research deals with dialogue and argumentation concerning knowledge construction processes and the investigation of social interaction as cognitive potential for learning. 
She studies 'community of inquiry' as method and context to develop higher order thinking skills, reflective capabilities, inclusive attitudes and citizenship agency. She is an expert on 'Philosophy for Children', a subject into which she has carried out a wide range of empirical research. She works also on improvization as teaching and learning procedure, new metaphor to rethink education for critical, creative and caring thinking, and framework toward co-construction of inclusive social environments.

\section{References}

Audigier, F. (2002). Concetti di base e competenze chiave per l'Educazione alla Cittadinanza Democratica [Base concepts and key competences for an Education to Democratic Citizenship]. Scuola \& Città, 1, 156-182.

Bakhtin, M. M. (1981). The dialogic imagination: Four essays. Austin: University of Texas Press.

Benhabib, S. (1996). Toward a deliberative model of democratic legitimacy. In S. Benhabib (Ed.), Democracy and differences: Contesting the boundaries of the political (pp. 67-94). Princeton: Princeton University Press.

Biggeri, M., \& Santi, M. (2012). The missing dimensions of children's well-being and well-becoming in education systems: Capabilities and philosophy for children. Journal of Human Development and Capabilities, 13, 373-395.

Bîrzéa, C. (2000). Education for democratic citizenship: A lifelong learning perspective. Project on "education for democratic citizenship". Strasbourg: Council for Cultural Co-Operation, CDCC.

Bloom, P. (2013). Just babies. The origin of good and evil. New York, NY: Crown Pub.

Bobbio, N. (1976). Quale socialismo? Discussione di un'alternativa [Which socialism? Discussion of an alternative]. Torino: Einaudi.

Bolivar, A. (2007). Educación para la ciudadanía: Algo más que una asignatura [Citizenship Education. More than a subject]. Barcelona: Graó.

Chevallard, Y. (1985). La transposition didactique. Du savoir savant au savoir enseigné [Didactic Transposition. From scholar to school knowledge]. Grenoble: La Pensée Sauvage.

Dewey, J. (1915). The public and its problems. Carbondale: University Press Drive.

Di Masi, D. (2012). Dialogical and reflective activities in the classrooms to improve moral thinking. In A. Dorit \& R. Reingold (Eds.), Changes in teachers' moral role. From passive observers to moral and democratic leaders (pp. 132-145). Rotterdam: Sense Publishers.

European Commission. (2005). Citizenship Education at school in Europe. Brussels: Eurydice.

Hermet, G. (1993). Culture et démocratie [Culture and democracy]. Paris: A. Michel.

Hoskins, B., Villalba, E., Van Nijlen, D., \& Barber, C. (2008). Measuring civic competence in Europe. A composite indicator based on IEA Civic Education Study 1999 for 14 years old in school. Luxembourg: JRC Scientific and Technical Reports.

Italian Ministerial Decree. (February 9 1979).

Italian Ministry of Education. (2012, September). Indicazioni Nazionali per il curriculo della scuola dell'infanzia e del primo ciclo d'istruzione [A National Guideline to Primary School Curriculum]. Firenze: Le Monnier.

Kelsen, H. (1984). La democrazia [A. M. Castronuovo, Trans.]. Bologna: II Mulino.

Kohlberg, L. (1984). Essays on moral development. Volume Il. The psychology of moral development. San Francisco: Harper \& Row.

Lave, J., \& Wenger, E. (1991). Situated learning. Legitimate peripheral participation. Cambridge: Cambridge University Press.

Lind, G. (1985). The theory of moral-cognitive judgment: A socio-psychological assessment. In G. Lind, H. A. Hartmann, \& R. Wakenhut (Eds.), Moral development and the social environment. Studies in the philosophy and psychology of moral judgment and education (pp. 21-53). Chicago, IL: Precedent Publishing.

Lind, G. (2008). The meaning and the measurement of moral judgment competence. A dual-aspect model. In D. Fasko \& W. Willis (Eds.), Contemporary philosophical and psychological perspective on moral development and education (pp. 185-220). Creskill: Hampton Press.

Lipman, M. (2003). Thinking in education. Cambridge: Cambridge University Press. 
Lipman, M., Sharp, A. M., \& Oscanyan F. S. (1980). Philosophy in the classroom. Philadelphia, PA:Temple University Press.

McCowan, T. (2008). Curricular transposition in citizenship education. Theory and Research in Education, $6,153-172$.

McLaughlin, T. H. (1992). Citizenship, diversity and education: A philosophical perspective. Journal of Moral Education, 21, 235-250.

O'Shea, K. (2003). Developing a shared understanding. A glossary of terms for education for democratic citizenship. Strasbourg: Council of Europe Publishing.

Perrenoud, P. (1998). L'évaluation des élèves. De la fabrication de l'excellence à la régulation des apprentissages [The Students' Evaluation. From Achievement to Learning. Between Two Logics]. Entre deux logiques. Brussels: De Boeck.

Petrucciani, S. (2014). Democrazia [Democracy]. Torino: Einaudi.

Power, F. C., Higgins, A., \& Kohlberg, L. (1989). Lawrence Kohlberg's approach to moral education. New york, NY: Columbia University Press.

Rest, J. R., Thoma, S. J., \& Edwards, L. (1997). Designing and validating a measure of moral judgment: Stage preference and stage consistency approaches. Journal of Educational Psychology, 89, 5-28.

Rogoff, B. (1995). Observing socio-cultural activity in three plans: Participatory appropriation, guided participation and apprenticeship. In J. Wertsch, P. del Rio, \& A. Alvarez (Eds.), Sociocultural studies of mind (pp. 139-164). New York, NY: Cambridge University Press.

Rogoff, B. (1996). Developmental transitions in children's participation in sociocultural activities. In A. Sameroff \& M. Haith (Eds.), The five to seven year shift (pp. 273-294). Chicago, IL: University of Chicago Press.

Santerini, M. (2010). La scuola della cittadinanza [The school of citizenship]. Roma: Laterza.

Santi, M. (2006). Ragionare con il discorso. Il pensiero argomentativo nelle discussioni in classe [Reasoning through dialogue. The aurgumentative thinking in the classroom discussions]. Napoli: Liguori Editore.

Santi, M. (2007). Democracy and inquiry. The internalization of collaborative rules in a community of philosophical discourse. In D. Camhy (Ed.), Philosophical foundations of innovative learning (pp. 110-123). Saint Augustin: Academia Verlag.

Santi, M., \& Di Masi, D. (2010, September 20). Inclusive citizenship? A philosophy for children project to promote student activity and participation in political life. Paper presented at the International Pre-Conference "Children's Capabilities", Amman.

Santi, M. \& Di Masi, D. (2014). Pedagogies to develop children's agency in schools. In C. Hart, M. Biggeri, \& B. Babic (Eds.), Agency and participation in childhood and youth (pp. 123-144). London: Bloomsbury Academic.

Sharp, M. (1993). The community of inquiry: Education for democracy. In M. Lipman (Ed.), Thinking children and education (pp. 337-345). Kendall: Hunt Publishing Company.

Torney-Purta, J., Lehmann, R., Oswald, H., \& Schulz, W. (2001). Citizenship and education in twenty-eight countries: Civic knowledge and engagement at age fourteen. Amsterdam: IEA.

Vansieleghem, N. (2005). Philosophy for children as the wind of thinking. Journal of Philosophy of Education, 39, 19-35.

Verret, M. (1975). Le temps des études [The time of studies]. Paris: Honoré Champion.

Vygotskij, L. S. (1978). Mind in society. Cambridge: Harvard University Press.

Walton, D. N., \& Krabbe, E. W. (1995). Commitment in dialogue. Basic concept of interpersonal reasoning. New York, NY: SUNY.

Wegerif, R. (2008). Dialogic or dialectic? The significance of ontological assumptions in research on educational dialogue. British Educational Research Journal, 34, 347-361.

Wegerif, R., Mercer, N., \& Dawes, L. (1999). From social interaction to individual reasoning: An empirical investigation of a possible socio-cultural model of cognitive development. Learning and Instruction, 9, 493-516.

Young, R. (1992). Critical theory and classroom talk. Clevedon: Multilingual Matters. 